The Soil Management Collaborative Research Support Program
Management Entity Office

Box 7113, North Carolina State University

Raleigh, NC 27695-71 3 USA - CGNET: TropSoils

Phone (919) 515-3922 - FAX (919) 515-3942

Email: Roger_Hanson@NCSU.EDU

December 14, 1993

Document Acquisitions

POL/CDIE/DI

Room 303 SA-18

Agency for International Development

Washington DC 20523-1803

ATT: Referred Publications supported by Project No. 9311311, Soil Management Collaborative Research Support Program under Grant No. DAN-1311-G-00-1049-00

Enclosed are two (2) copies of one (1) technical publication from the Soil Management Collaborative Research Support Program, Project No. 9311311, under Grant No. DAN-1311-G-00-1049-00.

Sincerely,

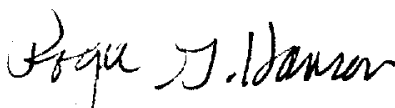

Roger G. Hanson

Director

RGH : nec

Enclosures

cc: Dr. Charles sloger 


\title{
Variable Sorghum Growth in Acid Soils of Subhumid West Africa
}

\author{
M. D. DOUMBIA \\ L. R. HOSSNER \\ Soil and Crop Sciences Department \\ Texas A\&M University \\ College Station, Texas
}

\section{A. B. ONKEN}

Texas Agricultural Experiment Station

Lubbock. Texas

\begin{abstract}
A sequence of experiments was conducted to define soil chemical proper ties associated with poor early growth of sorghum /Sorghum bicolor (L.) Moench/ in selected Grossarenic and Plinthic Paleustalfs or Eutric Nitosols (FAO Legend) of subhumid West Africa. Millet /Pennisetum americanum (L.) K. Schum/ appears to be tolerant to the soil problem under study. This soil constraint appears to inhibit sorghum growth and vield in all the soil positions of the toposequence of the Cinzana

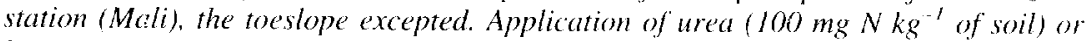
liming followed by an $N$ application neither prevented symptoms of poor growth nor significantly increased dry matter vield $(D M Y)$. However, application of $P$ alone or any treatment combination containing $P$ resulted in improved sorghum growth and yield. $D M Y$ was strongly correlated with Brav-1 $P\left(r=0.74^{*} *\right)$. Exchangeable soil Al had a significant but negative impact on DAY $(r=-0.42 * *)$. Amending the soil with Tilemsi rock phosphate (RP) or Diamou lime significantly increased exchangeable soil $\mathrm{Ca}^{2+}$ and $\mathrm{Mg}^{2+}$. Each of these amendments significantly reduced the concentrations of exchangeable soil $\mathrm{Al}^{3+}$. Phosphorus deficiency is one of the major factors limiting sorghum growth and vield in these Paleustalfs. The need for $P$ is more critical than that of $N$ in these soils. Aluminum toxicity is a secondary cause of this soil problem. An application as low as $2.5 \mathrm{mg} P \mathrm{~kg}$ ' of soil not only prevented symptoms of poor early growth but produced a significant dry matter increase in the greenhouse. A Bray-1 P level of $11.60 \mathrm{mg} \mathrm{P} \mathrm{kg.'} \mathrm{of} \mathrm{soil} \mathrm{appears} \mathrm{to} \mathrm{be} \mathrm{the} \mathrm{critical} \mathrm{Prequirement} \mathrm{for}$ optimum sorghum growth in these Paleastalfs.
\end{abstract}

Keywords spatial variability, sorghum, poor early growth. P deficiency, Al 10xicity

\section{Introduction}

The major constraints to crop production in Sahelian Africa include: (1) extremely deficient levels of $P$ and $N,(2)$ soil acidity, (3) soil spatial variability, and (4) limited available

Address correspondence to Mr. M. D. Doumbia. Soil and Crop Sciences Department. Texas A\&M University, College Station, TX 77843.

Received 4 September 1992: accepted 19 May 1993. 
soil water (Poulain, 1976; Stroosnijder, 1981; Wilding and Hossner, 1989; Takow et al., 1991). The interaction of these factors has resulted in marked variability in crop establishment, growth, and yield within a single field (Scott-Wendt et al., 1988; Wilding and Hossner, 1989; and Doumbia, 1990). These factors have resulted in a special problem for sorghum [Sorghum bicolor (L.) Moench] in some sandy soils of subhumid West Africa. Sorghum seedling emergence is, in general, uniform throughout the field. Then, I to 2 weeks after emergence, specific symptoms develop in areas irregularly distributed in the field. Symptoms of such poor early growth appear as purpling of the leaves, leaf yellowing, and death of the leaf tip. In extreme cases, seedlings become completely brown. The roots show necrotic spots and do not grow below the first 10 or $15 \mathrm{~cm}$ of topsoil. Plants in the most severely affected areas die.

Primary observations in farmers' fields in villages surrounding the Cinzana station and other sorghum-growing regions of Mali, especially sandy soils and toposequences in valley systems of landscape, have indicated that this problem is not limited to the Cinzana area. Leaf yellowing or purpling on affected seedlings in these fields was similar to observations made in the station. However, very few affected seedlings in these fields displayed the strong brown color observed in the most severely affected areas of the station. Local cultivars used by these farmers are less affected because they have been selected over a long period of time for survival and stability over a wide range of environmental conditions. These cultivars are able to survive under less favorable environments where nutrient stresses are acute. Under such conditions, improved and cxotic varieties generally fail to grow. The extreme form observed in the Cinzana station may be due to the use of improved and exotic sorghums and acidifying effects of $\mathrm{N}$ fertilizers. A similar case of poor early sorghum growth was reported in Plinthic Paleustalfs of Burkina Faso (Pichot et al., 1981). Poor seedling growth and establishment of sorghum in these soils were caused by Al toxicity.

Other cases of $\mathrm{Al}$ toxicity have been reported in soils of the semiarid and subhumid zones of West Africa. For example, aluminum toxicity-induced growth limitation and decrease in peanut (Arachis hypogea L.) yields in Sénégal (Piéri, 1974) and poor root development and low sugarcane [Saccharum officinarum L.) yield under irrigation in Burkina Faso (Namoro, 1983). Studies by Scott-Wendt et al. (1988) and Davis-Carter (1989) indicated that exchangeable Al was primarily responsible for poor early pearl millet [Pennisetum americanum (L.) K. Schum] growth in the poorly buffered sandy soils of the semiarid Sahelian environment of Niger. However, Manu et al. (1991) reported that Al toxicity was not a problem of regional concern in selected sandy to sandy loam soils of West Africa but instead should be a focus of localized research and control.

Soils of the semiarid and subhumid regions of Mali and other regions of West Atrica are commonly acid, weathered, and characterized by a dominance of kaolinite and sesquioxides (Juo and Fox, 1977; Wilding and Hossner, 1989; Takow et al., 1991; Manu et al., 1991). Phosphorus is the most deficient and plant growth-limiting nutrient in these soils (Enwezor and Moore. 1966; Pichot and Roche. 1972: Poulain, 1976; Manu et al., 1991). Jones and Wild (1975) documented that P deficiency could be so acute that plant growth stopped once the seed reserve of $P$ had been depleted. In addition, Davis-Carter (1989) and Gardiner (1990) found that $P$ was one of the soil chemical variables most related to uneven stand establishment and crop growth in Psammentic Palcustafs of Western Niger.

This paper describes a sequence of experiments designed to define some of the soil chemical propertics associated with poor early sorghum growth in selected Paleustalts of West Africa. The distribution of the problem along the different soil positions of the 
Cinzana toposequence was first evaluated. Then, a soil amendment study was performed to identify plant nutrients that contribute most significantly to poor early sorghum growth in these soils. In addition, a response curve was established for the most deficient nutrient.

\section{Materials and Methods}

\section{The Experimental Site}

The Cinzana station is located near $5^{\circ} 56^{\prime} \mathrm{W}$ and $13^{\circ} 18^{\prime} \mathrm{N}$. It is approximately $281 \mathrm{~m}$ above sea level and covers an area of $277 \mathrm{ha}$. The station receives an annual mean rainfall of approximately $650 \mathrm{~mm}$ from May to October; about one-half of that rain falls in July-August, and rainfall intensity of $40 \mathrm{~mm}$ per hour is common. The annual mean temperature ranges from $28^{\circ}-30^{\circ} \mathrm{C}$, with minimum and maximum temperatures of $8^{\circ} \mathrm{C}$ and $40^{\circ} \mathrm{C}$, respectively. The native vegetation is mostly dominated by shrub and grass species. Soils in the Cinzana station are distributed according to a toposequence which results in different soil positions or hillslope elements (Fig. 1): summit, shoulder, backslope, footslope, and toeslope (Ruhe, 1960). The toeslope portion of the area is extented about $7 \mathrm{~km}$ to the Bani river, a major tributary of the Niger river. This type of toposequence or valley system of landscape is very common in Mali and in many other regions of West Africa (Ouattara, 1990).

\section{Influence of Soil Positions}

An observation plot was planted in each toposequence position of the Cinzana station (Fig. 1) to evaluate the distribution of the abnormal sorghum [Sorghum bicolor (L.) Moench] growth problem. Each plot consisted of a subplot of sorghum (genotype Malisor 84-5) and another of millet [Pennisetum americanum (L.) K. Schum]. Each subplot was 7 rows $\times 5$ $\mathrm{m}$ long. The spacing between rows was $75 \mathrm{~cm}$, and sorghum or millet (genotype HKP) was planted in hills $50 \mathrm{~cm}$ apart. Planting hills were thinned to 2 plants. Two replications were planted on 6 July 1990. Germinated planting hills and planting hills showing the symptoms of poor growth were counted in each subplot. The percentage of planting hills showing the symptoms was calculated. Each plot was sampled (first $15 \mathrm{~cm}$ of topsoil) for laboratory analysis (duplicate determination). Soil $\mathrm{pH}$ was determined in water $(1: 2$ soil: water ratio) using a glass electrode and a $\mathrm{pH}$ meter. Exchangeable acidity and $\mathrm{Al}$ were extracted using the $\mathrm{KCl}$ method described by Thomas (1982) and measured by titration.

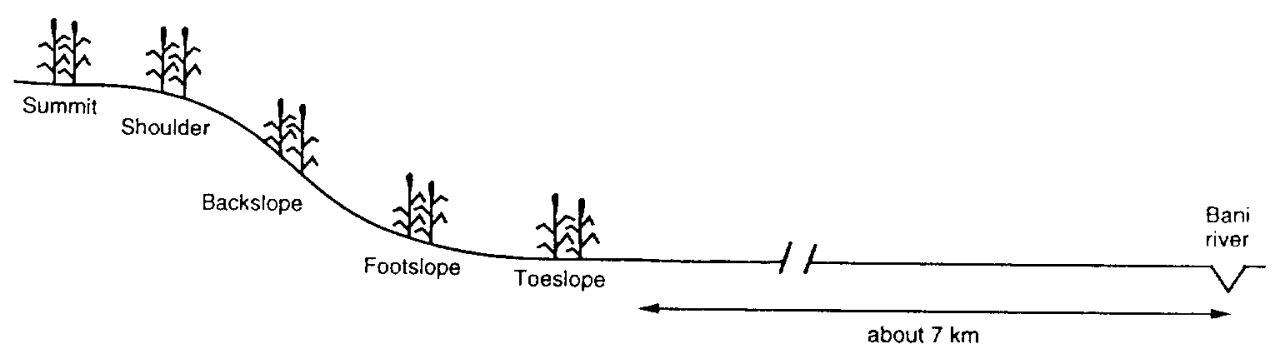

Figure 1. Approximative illustration of the toposequence of the Cin/ana station. Hillslope elements indicated according to their respective positions on the landscape (Adapted from Ruhe, 1960). The distance from the summit first plot to the last of the toeslope is about $1.8 \mathrm{~km}$. The cumulative slope is about $0.5 \%$. 
Exchangeable cations were extracted with $\mathrm{NH}_{4} \mathrm{OAc}(\mathrm{pH}=7.0)$ and measured by atomic absorption as described by Thomas (1982), Knudsen et al. (1982), and Lanyon and Heald (1982). The effective cation exchange capacity (ECEC) was estimated by summing the exchangeable cations and the exchangeable acidity. Aluminum $+\mathrm{H}^{+}$saturation was calculated as a percentage of the ECEC. Plant available $P$ was extracted with Bray-1 solution as outlined by Olsen and Sommers (1982) and measured with a Technicon AutoAnalyzer. (Technicon Industrial Systems, 1977). Particle size distribution was determined by the hydrometer method described by Gee and Bauder (1986). Organic matter content was estimated according to the Walkley-Black procedure (extraction with $\mathrm{K}_{2} \mathrm{Cr}_{2} \mathrm{O}_{7}$ and estimation by titration) outlined by Nelson and Sommers (1982).

\section{Soil Amendment Study}

This experiment was conducted in the greenhouse (in May and under natural light) using a sample $(0$ to $15 \mathrm{~cm})$ of sandy, mixed, isohyperthermic, Plinthic Paleustalfs or Eutric Nitosols (FAO Legend) collected from the backslope, in a plot where poor early sorghum growth had been observed. Selected properties of the soil are given in Table 1. A bulk soil sample was collected, air-dried, ground, and passed through a 2-mm screen. A 10-L plastic container filled with $10 \mathrm{~kg}$ of soil served as the experimental unit. The experimental units were placed at random on the floor of the greenhouse.

The study was a factorial experiment conducted as a completely randomized design with 3 replications. Factors evaluated were 4 soil amendments and 6 nutrient combinations. The amendments included: (1) check, (2) lime requirement (LR), (3) $2 \times \mathrm{LR}$, and (4) rock phosphate. Nutrient combinations included: (1) no nutrient, (2) N as urea, (3) P as triple superphosphate (TSP), (4) $\mathrm{N}$ and $\mathrm{P}$ as urea and $\left(\mathrm{NH}_{4}\right)_{2} \mathrm{HPO}_{4}$ (DAP), respectively, (5) $\mathrm{N}$ and $\mathrm{P}$ as urea and TSP, (6) N, $\mathrm{P}$, and $\mathrm{K}$ as urea, TSP, and $\mathrm{KNO}_{3}$, respectively. The LR was based on exchangeable Al as suggested by Kamprath (1970). The liming material was Diamou lime, a local material containing approximately $90 \% \mathrm{CaO}$. The rock phosphate (RP) source was Tilemsi RP, a local resource containing $12.22 \% \mathrm{P}$ and $30.8 \% \mathrm{Ca}$ (Truong et al., 1978). It was applied at a rate of $102 \mathrm{mg}$ P per cmole(+) of exchangeable acidity (Sanchez and Uehara, 1989). Nitrogen was applied at a rate of $100 \mathrm{mg} \mathrm{kg}^{-1}, \mathrm{P}$ at

$100 \mathrm{mg} \mathrm{kg}^{-1}$, and $\mathrm{K}$ at $50 \mathrm{mg} \mathrm{kg}^{-1}$. Lime and $\mathrm{P}$ amendments were homogeneously mixed

Table 1

Selected Properties of a Sandy, Mixed, Hyperthermic Plinthic Paleustalf (USDA Soil Taxonomy) or Eutric Nitosols (FAO Legend) Profile of the Cinzana Station

\begin{tabular}{lcccc}
\hline & \multicolumn{4}{c}{ Horizon } \\
\cline { 2 - 5 } Parameter & $\mathrm{Ap}$ & $\mathrm{Bt2c}$ & $\mathrm{Bv2}$ & $\mathrm{Bv4}$ \\
\hline Depth $(\mathrm{cm})$ & $0-26$ & $3.5-50$ & $77-101$ & $150-180$ \\
Clay $(\%)$ & 5.1 & 7.3 & 12.0 & 28.7 \\
Sand $(\%)$ & 85.8 & 82.2 & 76.2 & 59.3 \\
$\mathrm{pH}\left(\mathrm{H}_{2} \mathrm{O}\right)$ & 5.5 & 5.1 & 4.9 & 4.6 \\
Organic C $(\%)$ & 0.13 & 0.14 & 0.15 & 0.17 \\
ECEC lcmol(+) kg 'I & 0.90 & 1.15 & 2.13 & 2.72 \\
$\mathrm{Al}(\%)$ " & 34 & 46 & 49 & 36 \\
Bray-1 $\mathrm{P}\left(\mathrm{mg} \mathrm{kg}^{-1}\right)$ & 5.24 & & & \\
\hline
\end{tabular}

"Al saturated in \% of ECEC. 
with the soil prior to planting. Nitrogen and $\mathrm{K}$ were applied in 2 split applications (2-leaf and 3-leaf stages) with irrigation water.

Malisor 84-5, a locally improved sorghum genotype that is sensitive to soil acidity. was used. Sorghum was thinned to 3 plants per container and grown for 37 days during which the soil moisture content was brought to field capacity by weighing.

The crop data collected included dry matter yield (DMY). At the end of the experiment, each experimental unit was sampled (soil and plant) for laboratory analysis. Laboratory analyses were performed to determine the effects of treatments on selected soil chemical properties and nutrient concentrations in the plant shoot. Soil samples were analyzed for $\mathrm{pH}, \mathrm{ECEC}$, exchangeable acidity and $\mathrm{Al}$, and available $\mathrm{P}$ (Bray-1). Plant samples were wet-digested (Nelson and Sommers, 1980), and analyzed for $\mathrm{N}$ and $\mathrm{P}$ (Technicon Industrial Systems, 1977) and by atomic absorption for Ca (Lanyon and Heald, 1982), Al (Barnhisel and Bertsch, 1982), Mn (Gambrell and Patrick, 1982), and Fe (Olson and Ellis, 1982).

Data were statistically analyzed using the General Linear Model procedure of SAS (SAS, 1985). In addition, nutrient means were tested within each amendment and across the different amendments. Dry matter yield was correlated with various soil chemical properties and shoot nutrient concentrations.

\section{Response to Applied P}

The greenhouse experiment was carried out as an initial step on which to base P rates for a field study to measure sorghum response to applied $P$ in Grossarenic and Plinthic Paleustalfs of the Cinzana station or Eutric Nitosols (FAO Legend).

This experiment was designed as a $2 \times 10$ (lime $\times$ phosphorus) factorial experiment (completely randomized design with 3 experimental units per treatment). The lime factor consisted of a control and the lime requirement defined earlier. Rates of $\mathrm{P}$ included the following: $0,2.5,5,10,15,20,40,60,80$, and $100 \mathrm{mg} \mathrm{kg}$ '. All treatments received 100 $\mathrm{mg} \mathrm{N} \mathrm{kg}{ }^{-1}$ (as urea and $\mathrm{KNO}_{3}$ ) and $50 \mathrm{mg} \mathrm{K} \mathrm{kg}^{-1}$ (as $\mathrm{KNO}_{3}$ ) so that these nutrients would not limit sorghum growth.

The limed soil was subjected to 3 cycles of wetting-drying before planting during which exchangeable acidity was monitored for neutralization of exchangeable Al. Then. $P$ rates were applied (mixing with dry soil) as TSP. Other experimental materials, methods, and conditions were the same as in the first greenhouse experiment. Plants were grown for 31 days.

\section{Results and Discussion}

\section{Influence of Soil Positions}

One of the striking features of this problem is that millet seedlings, across the different soil positions, did not display the dark purple or brown color symptom that is typical on affected sorghum plants. Very slight yellowing was occasionally seen on millet seedlings, but the strong purple or brown color that is typical of affected sorghum leaves was not seen on millet seedlings at any soil position. In addition, no sorghum planting hill displayed stunted growth and leaf purpling in the heavy toeslope soil. These observations suggest that only sandy soils of the toposequence seem to be affected.

Chemical properties of the different soil positions indicated that the toeslope soil had higher ( 2 to 10 times) concentrations of exchangeable bases. However, the concentration 
of $\mathrm{P}$ that could be extracted with Bray-1 solution was very low in the toeslope soil (3.31 $\mu \mathrm{g} \mathrm{P} \mathrm{g}^{-1}$ of soil) and high in the shoulder soil $\left(17.65 \mu \mathrm{g} \mathrm{P} \mathrm{g}^{-1}\right)$. Application of heavy rates of Tilemsi RP to sandy soils of the toposequence and optimum sorghum growth at the time of soil sampling may explain these differences in Bray-1 P concentrations. The toeslope soil contained about $0.02 \mathrm{cmol}(+)$ of exchangeable $\mathrm{Al}^{3+} \mathrm{kg}^{-1}$ of soil (15 times less than the footslope soil). Organic matter content doubled from the summit to the toeslope $(0.39 \%$ organic $\mathrm{C})$.

The fact that millet roots have been found to be highly tolerant to high concentrations of exchangeable soil $\mathrm{Al}^{3+}$ (Long, 1972: cited by Brenes and Pearson, 1973) may help explain the tolerance of millet to the problem. Sorghum is considered to be intolerant to high exchangeable soil Al (Sanchez, 1976). Walker et al. (1975) found sorghum more sensitive than millet to excesses of $\mathrm{Al}$ and $\mathrm{Mn}$ in plant tissues. In addition, millet seems to require less $P$ than sorghum (Ajakaiye, 1979; Fox et al., 1974). Millet also seems to be more tolerant than sorghum to low soil $\mathrm{pH}$ (Walker et al., 1975).

\section{Dry Matter Yield}

Plant symptoms of poor early growth similar to those observed in the field were displayed only when either no nutrient or urea (100 $\mathrm{mg} \mathrm{N} \mathrm{kg} \mathrm{'} \mathrm{of} \mathrm{soil)} \mathrm{was} \mathrm{combined} \mathrm{in} \mathrm{the} \mathrm{limed}$ or unamended soil. The application of $100 \mathrm{mg} \mathrm{N} \mathrm{kg} \mathrm{'neither} \mathrm{prevented} \mathrm{the} \mathrm{symptoms} \mathrm{of}$ poor early growth nor resulted in a significant increase in DMY (Figure 1). The application of $\mathrm{P}$ alone or any treatment combination containing $\mathrm{P}$ resulted in good sorghum growth and yield (Fig. 2). In addition, symptoms of poor early growth as seen on sorghum grown in these Paleustalfs strongly matched those described and pictured by Krant $z$ and Melsted (1964) as severe P deficiency.

\section{Influence of Soil Parameters on DMY}

Bray-1 extractable P concentrations of the different treatments showed about the same pattern as that of DMY (Fig. 2). This may be explained by the significant, positive correlation $(r=0.74 * *)$ between DMY and Bray-1 P. The soil phosphorus concentration for treatment combinations containing no $P$ was around $6 \mathrm{mg} \mathrm{kg}^{-1}$ - a value for extractable $\mathrm{P}$ ranked in the low range for Bray-1 $\mathrm{P}$ (Olsen and Sommers, 1982). It was under these treatments that symptoms of poor growth and very low DMY were recorded (Fig. 2).

Correlation analyses between DMY and selected soil chemical properties indicated that exchangeable soil $\mathrm{Al}$ had a significant but negative impact on DMY $(r=-0.42 * *)$. In fact, the $\mathrm{Al}$ saturation percentage of the soil sample used (34\%) was well above the $15 \%$ suggested as critical for sorghum in Puerto Rican Oxiso!s and Ultisols (Abruna et al., 1975).

\section{Sorghum Mineral Composition}

Among the mineral concentrations determined in the shoot, P correlated best $\left(r=0.47^{* *}\right)$ with DMY, although $r^{2}=0.22$. Ajakaiye (1979) reported that sorghum grew best when the $P$ concentration in its shoot (about 24 days after planting) was within the range of 2.2-8.1 $\mathrm{g} \mathrm{kg}^{-1}$. The Phosphorus concentration was less than $2 \mathrm{~g} \mathrm{~kg}^{-1}$ in the shoot of plants grown without $\mathrm{P}$ application. Shoot concentration ranged from $4.18-7.25 \mathrm{~g} \mathrm{P} \mathrm{kg}$ ' when $\mathrm{P}$ was applied.

The concentration of $\mathrm{Al}$ in the shoot was near the toxic level of $500 \mathrm{mg} \mathrm{kg}^{-1}$ reported 


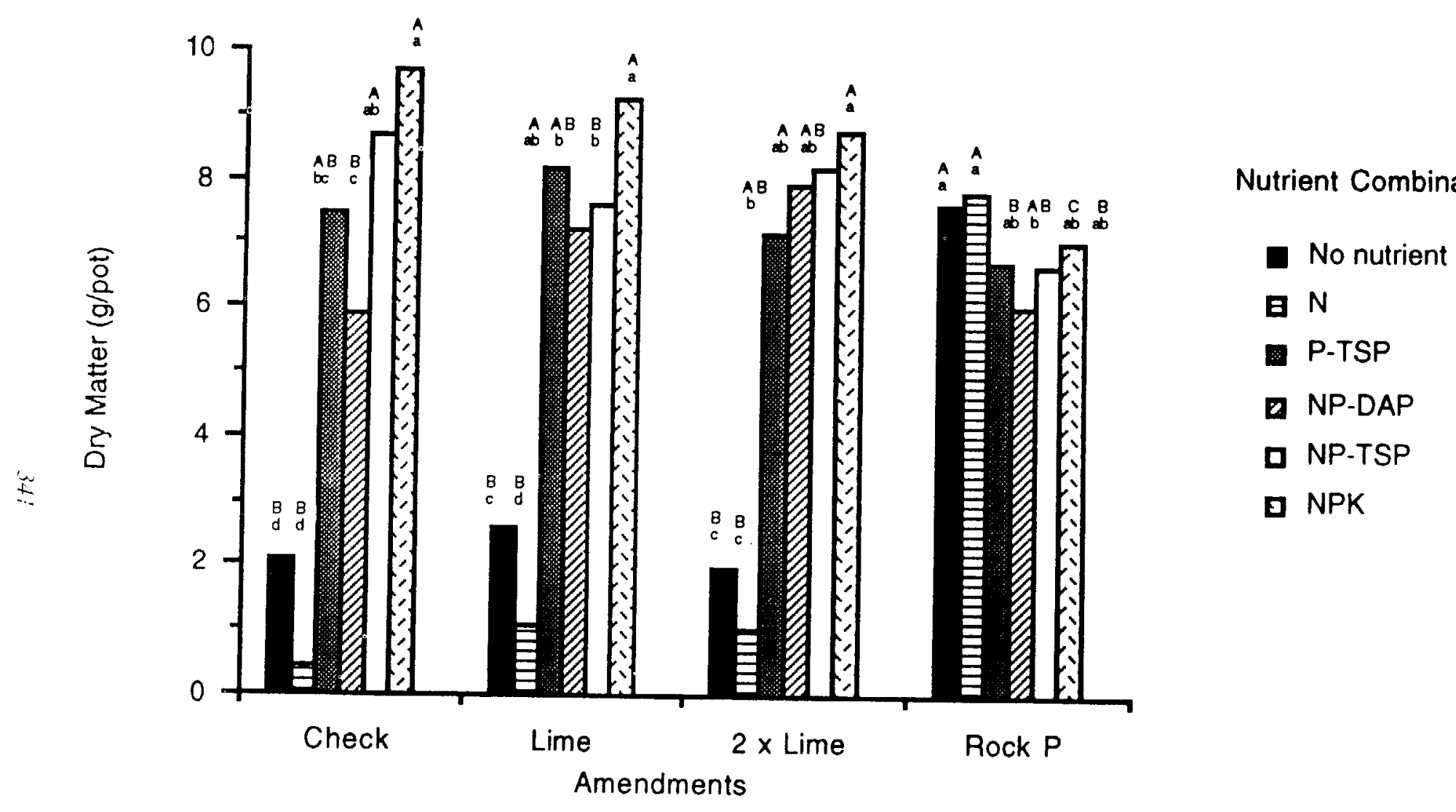

Figure 2. Sorg! um dry matter yield ( 3 plants grown for 37 days) as intluenced by lime, rock phosphate, and various nutrient combinations in the greenhouse (under natural light). Interaction means wcre tested at the $\mathrm{P}=0.05$ level, using Duncan's multiple range lest as follows: lower case letters indicate significance of nutrients within each amendment while capital letters indicate significance of amendments within each nutrients. 
by Grundon et al. (1987) when either no nutrient, N, or no amendment was applied. These treatments had very poor sorghum growth and very low DMY (Fig. 2). The concentration of $\mathrm{Al}$ in the shoot had a significant but negative influence on DMY $(r=-0.31 * *)$.

\section{Response to Applied P}

Symptoms of early poor sorghum growth were seen only in treatment combinations containing no P. Combining lime with either N or NK did not prevent the appearance of the above symptoms.

A rate as low as $2.5 \mathrm{mg} \mathrm{P} \mathrm{kg} \mathrm{P}^{-1}$ of soil not only prevented the plant symptoms but also produced significant increases in sorghum growth and dry matter yield (Fig. 3). This observation indicates that these soils have an cxtremely low P fixing capacity. Increasing the rate of $\mathrm{P}$ beyond $15 \mathrm{mg} \mathrm{P} \mathrm{kg}{ }^{-1}$ did not result in a significant increase in dry matter production. Liming significantly enhanced the effects of applied $\mathrm{P}$ on dry matter yield only at $\mathrm{P}$ rates lower than $15 \mathrm{mg} \mathrm{P} \mathrm{kg}^{-1}$ (Fig. 3).

\section{Conclusions}

Millet appears to be tolerant to the soil problem under study. Sorghum growth and yield appear to be inhibited in all the hillslope elements. the toeslope excepted. Compared with the other hillslope elements of the toposequence used, the toeslope soil had a negligible $\mathrm{Al}^{3+}+\mathrm{H}^{+}$saturation, higher organic matter content. and higher concentrations of exchangeable $\mathrm{Ca}^{2+}$ and $\mathrm{K}^{+}$.

The data for plant symptoms of early poor growth, DMY, plant mineral composition. and selected soil chemical properties suggest that $P$ deficiency is one of the major factors limiting sorghum growth and yield in these Paleustalls. The need for $P$ is more acute than that of $\mathrm{N}$ in these soils. Exchangeable $\mathrm{Al}^{3+}$, due 10 its negative and significant impact on dry matter yield, is a secondary cause of this soil problem.

Diamou lime offers potential as an agricultural amendment. Tilemsi RP, as indicated by this research and previous work (Thibout et al., 1981), can be directly used to improve crop growth and yield in sandy, acid soils of the subhumid and semiarid tropics. Each of these amendments increased the concentration of exchangeable $\mathrm{Ca}^{2+}$ and $\mathrm{Mg}^{2+}$ and decreased the concentration of exchangeable $\mathrm{Al}^{3+}$.

These soils are very deficient in $\mathrm{P}$ and have an extremely low $\mathrm{P}$ fixing capacity. Sorghum plants responded to applications as low as $2.5 \mathrm{mg}$ soluble $\mathrm{P} \mathrm{kg} \mathrm{'}$. An application of $15 \mathrm{mg} \mathrm{P} \mathrm{kg} \mathrm{'} \mathrm{of} \mathrm{soil} \mathrm{in} \mathrm{a} \mathrm{greenhouse} \mathrm{study} \mathrm{appears} \mathrm{to} \mathrm{provide} \mathrm{adequate} \mathrm{P}$ for cptimum sorghum growth in these Grossarenic and Plinthic Paleustalfs. This rate is slightly higher than the recommended economic rate of $20 \mathrm{~kg} \mathrm{Pha}^{-1}$ for sorghum and pearl millet in most soils of Mali (Poulain, 1976). Soil, DMY, and plant tissue data suggest that a Bray-1 P concentration of $11.60 \mathrm{mg} \mathrm{P} \mathrm{kg}{ }^{-1}$ is the critical $\mathrm{P}$ level required for optimum sorghum growth in these soils.

\section{Acknowledgments}

This paper is a contribution from TropSoils [LSAID Grant DAN-1311-G-SS-6018-00 (SM-CRSP-042)]. 


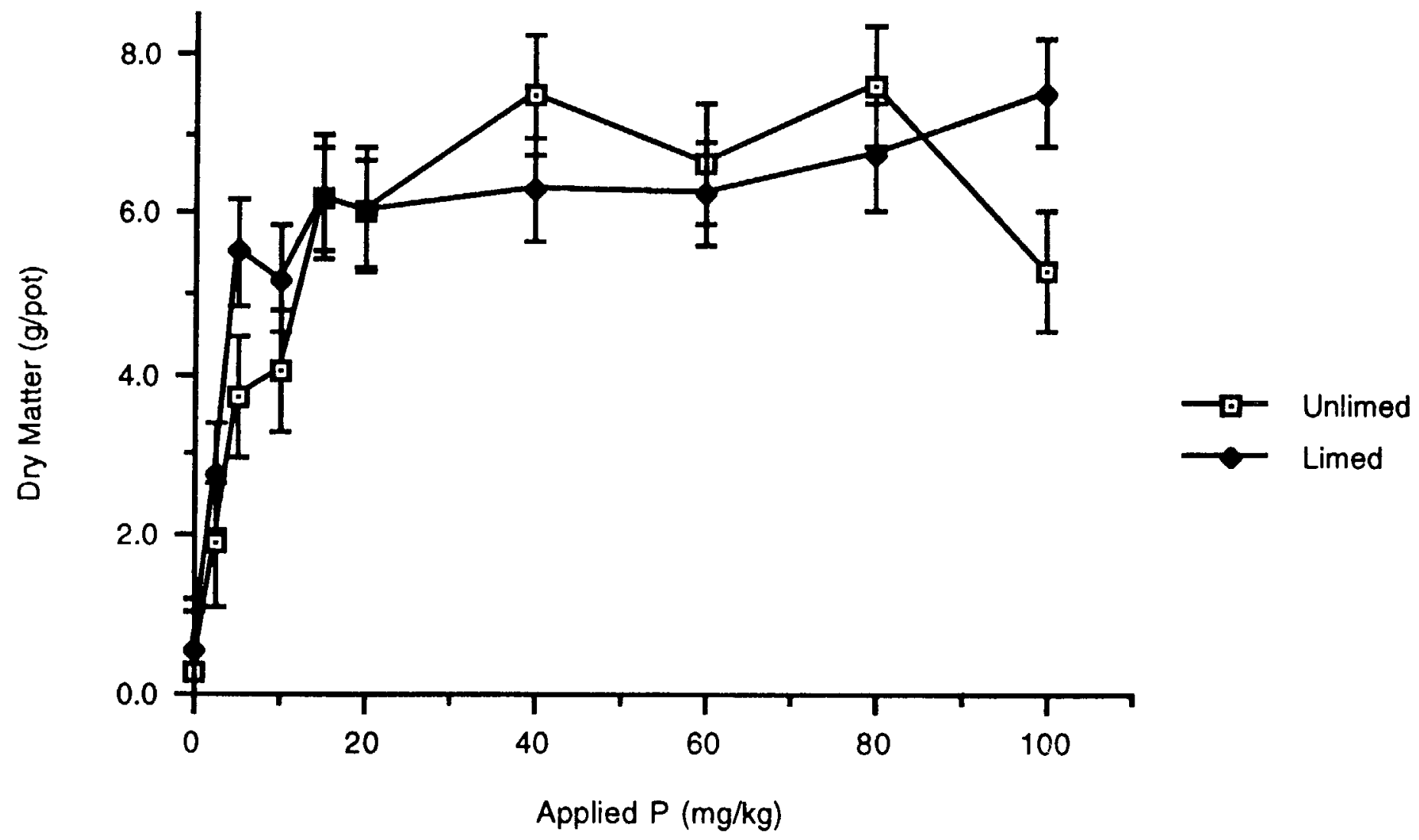

Figure 3. Sorghum dry matter yield ( 3 plants grown for 31 days) as influneced by lime, $\mathrm{P}$ rates, and mineral supplemenı ( $\mathrm{N}$ and $\mathrm{K}$ ) in the greenhouse (under natural light). Vertical bars indicate standard errors. 
The authors acknowledge the contributions of Messrs. Adama "N'talah" Konate, Gaoussou "Violon" Soumounou, Oriyerou Perou, Kabaou Dolo, and Dr. Aboubacar Touré.

\section{References}

Abruna, F., R. W. Pearson, and R. Perez-Escolar. 1975. Lime responses of corn and beans grown on typical Ultisols and Oxisols of Puerto Rico, pp. 261-328, in E. Bornemisza and A. Alvarado, eds., Soil Management in Tropical America. North Carolina State University, Raleigh, NC.

Ajakaiye, C. O. 1979. Effect of phosphorus on growth and iron nutrition of millet and sorghum. Plant and Soil 51:551-561.

Barnhisel, R., and P. M. Bertsch. 1982. Aluminum, pp. 275-300, in A. L. Page, R. H. Miller, and D. R. Keeney, eds., Methods of Soil Analysis, Part 2, 2nd ed. American Society of Agronomy, Madison, WI.

Brenes, E., and R. W. Pearson. 1973. Root response of three gramineae species to soil acidity in an Oxisol and an Ultisol. Soil Science 116:295-302.

Davis-Carter, J. G. 1989. Influence of spatial variability of soil physical and chemical properties on the rooting patterns of pearl millet and sorghum. Ph.D. dissertation, Soil and Crop Sciences Department, Texas A\&M University, College Station, Texas.

Doumbia, M. D. 1990. Acid soil fertility at the Cinzana station, Mali (West Africa). M. S. Thesis, Soil and Crop Sciences Department, Texas A\&M University, College Station, TX.

Enwezor, W. O., and A. W. Moore. 1966. Phosphorus status of some Nigerian soils. Soil Science 102:322-328

Fox, R. L., R. K. Hashimoto, J. R. Thompson, and R. S. de la Pena. 1974. Comparative external phosphorus requirements of plants growing in tropical soils. Tenth International Congress on Soil Science (Moscow) 4:232-239.

Gambrell, R. P., and W. H. Patrick, Jr. 1982. Manganese, pp. 313-322, in A. L. Page, R. H. Miller, and D. R. Keeney, eds., Methods of Soil Analysis. Part 2, 2nd ed. American Society of Agronomy, Madison. WI.

Gardiner, J. B. 1990. Spatially variable fertility in a psammentic Paleustalf of Western Niger. M.S. Thesis, Soil and Crop Sciences Department, Texas A\&M University, College Station. TX.

Gee, G. W., and J. W. Bauder. 1986. Particle size analysis, pp. 383-411, in A. Klute, ed., Methods of Soil Analysis, Part 1, 2nd ed. American Society of Agronomy, Madison, WI.

Grundon, N. J., D. G. Edwards, P. N. Takkar, C. J. Asher, and R. B. Clark. 1987. Nutritional Disorders of Grain Sorghum. Monograph Series No. 2. Australian Center for International Agricultural Research (ACIAR). Canberra, Australia.

Jones, M., and A. Wild. 1975. Soils of the West African Savanna: the maintenance and improvement of their fertility. Technical Communication No. 55. Commonwealth Agricultural Bureaux. Farnham Royal, U.K.

Juo, A. S. R., and R. L. Fox. 1977. Phosphorus sorption characteristics of some bench-mark soils of West Africa. Soil Science 124:370-376.

Kamprath, E. J. 1970. Exchangeable aluminum as a criterion for liming leached mineral soils. Soil Science Society of America Proceedings 24:252-254

Knudsen D, G. A. Peterson, and P. F. Pratt. 1982. Lithium, sodium, and potassium, pp. 225-245, in A. L. Page, R. H. Miller, and D. R. Keeney, eds., Methods of Soil Analysis, Part 2, 2nd ed. American Society of Agronomy, Madison, WI.

Krantz, B. A. and S. W. Melsted. 1964. Nutrient deficiencies in corn, sorghum, and small grains, pp. 25-57, in H. B. Sprague, ed., Hunger Signs in Crops, 3rd ed. David Mcka New York. New York.

Lanyon, L. E., and W. R. Heald. 1982. Magnesium, calcium, strontium, and barium, pp. 247-260, in A. L. Page, R. H. Miller, and D. R. Keeney, eds., Methods of Soil Analysis, 2nd ed., Part 2. American Society of Agronomy, Madison, WI. 
Manu, A., A. Bationo, and S. C. Geiger. 1991. Fertility status of selected millet producing soils of West Africa with emphasis on phosphorus. Soil Science 152:315-320.

Namoro, B. 1983. Influence de l'acidité d'un sol sableux sur le développement racinaire et le rendement de la canne à sucre dans un périmètre irrigué de Haute Volta. Thesis, Doc.. Ing.. USTL, Montpellier, France.

Nelson, D. W., and L. E. Sommers. 1980. Total nitrogen analysis for soil and plant tissues. Journal of the Association of Official Analvtical Chemists 63:770-778.

Nelson, D. W., and L. E. Sommers. 1982. Total carbon, organic carbon, and organic matter, pp. 539-579, in A. L. Page, R. H. Miller, and D. R. Keeney, eds., Methods of Soil Analvsis, Part 2, 2nd ed. American Society of Agronomy, Madison, WI.

Olsen, S. R., and L. E. Sommers. 1982. Phosphorus, pp. 403-427, in A. L. Page, R. H. Miller, and D. R. Keeney, eds., Methods of Soil Analysis, Part 2, 2nd ed. American Society of Agronomy. Madison, WI

Olson, R. V., and R. Ellis, Jr. 1982. Iron, pp. 301-312. in A. L. Page, R. H. Miller. and D. R. Keeney, eds., Methods of Soil Analysis, Part 2, 2nd ed. American Society of Agronomy. Madison, WI.

Ouattara, Mamadou. 1990. A study of two toposequences of the dry valley systems of Western Niger (West Africa). Ph.D. dissertation, Soil and Crop Sciences Department, Texas A\&M University. College Station, TX.

Pichot, J., and P. Roche. 1972. Phosphore dans les sols tropicaux. Agronomie Tropicale 27:939-965.

Pichot, J., M. P. Sedogo, J. F. Poulain, and J. Arrivets. 1981. Evolution de la fertilité d'un sol ferrugineux tropical sous l'influence de fumures minérales et organiquies. Agronomie Tropicale 36:122-133.

Piéri, C. 1974. Premiers résultats expérimentaux sur la sensibilité de l'arachide à la toxicité aluminique. Agronomie Tropicale 29:685-697.

Poulain, J. F. 1976. Amélioration de la fertilité des sols agricoles du Mali. Bilan de treize années de travaux (1962-1974). Agronomie Tropicale 31:402-416.

Ruhe, R. V. 1960. Elements of the landscape. Transactions of the 7 th International Congress of Soil Science (Madison Wisconsin) 4:165-170.

Sanchez, P. A. 1976. Soil acidity and liming, pp. 223-253, in Properties and Management of Soils in the Tropics. John Wiley, New York, NY.

Sanchez, P. A., and G. Uehara. 1980. Management considerations for acid soils with high phosphorus fixation capacity, pp. 263-310, in F. E. Khasawneh, E. C. Sample, and E. J. Kamprath, eds., The Role of Phosphorus in Agriculture. American Society of Agronomy, Madison, Wl.

SAS. 1985. SAS User's Guide: Statistics, Version 5. SAS Institute, Cary, NC.

Scott-Wendt, J., L. R. Hossner, and R. G. Chase. 1988. Variability in millet (Pennisetum americanum) fields in semiarid West Africa. Arid Soil Research and Rehabilitation 2:49-58.

Stroosnijder, L. 1981. A soil water balance study of the Malian Sahel. Agronomy Abstracts 1981, p. 144.

Takow, J. A., M. D. Doumbia, and L. R. Hossner. 1991. Acid soil profiles of the semiarid and subhumid tropics in Central and West Africa, pp. 313-320, in R. J. Wright, ed, Plant-soil Interactions at Low pH. Kluwer Academic Publishers, The Netherlands.

Technicon Industrial Systems. 1977. Individual/simultaneous Determination of Nitrogen and/or Phosphorus in BD Acid Digests. Technicon Industrial Systems, Tarrytown, NY.

Thibout, F., M. F. Traore, C. Pieri, and J. Pichot. 1980. L'utilisation agricole des phosphates naturels de Tilemsi (Mali). Synthèse des résultats de la recherche agronomique sur les cultures vivrières et oléagineuses. Agronomie Tropicale 35:240-249.

Thomas, G. W. 1982. Exchangeable cations, pp. 159-164, in A. L. Page, R. H. Miller, and D. R. Keeney, eds., Methods of Soil Analysis, Part 2, 2nd ed. American Society of Agronomy. Madison, WI.

Truong, G. W., J. Pichot, and P. Bernard. 1978. Caratérisation et comparaison des phosphates tricalciques d'Afrique de l'Ouest en vue de leur utilisation directe en agriculture. Agronomie Tropicale 33:136-145. 
Walker, M. E., W. H. Marchant, and W. J. Ethredge. 1975. Effects of soil pH on forage yield and chemical composition of sorghum and millet. Agronomy Journal 67:191-193.

Wilding, L. P., and L. R. Hossner. 1989. Causes and effects of acidity in Sahelian soils, pp. 215-227, in ICRISAT, Soil, Crop, and Water Management Systems for Rainfed Agriculture in the Sudano-Sahelian Zone: Proceedings of an International Workshop, 7-11 January 1987. ICRISAT Sahelian Center, Niamey, Niger. ICRISAT, Patancheru, India. 